\title{
Theoretical Old-Age Pension Benefits and Replacement Rates in the Baltic States: A Retrospective Simulation
}

\author{
Olga Rajevska \\ University of Latvia
}

\begin{abstract}
The author presents a comparative analysis of old-age pension systems in Estonia, Latvia and Lithuania using a method of retrospective simulation run on a self-developed model. The model baseline case is a person retiring in December 2014 after 40 years of service with nationwide average salary. Other cases include lowand high-earners, funded schemes participants and simulations for modified notional capital valorisation formulae. Three study countries return very dissimilar results, which is caused by differences in their pension systems' designs. Lack of non-contributory element (basic pension) in Latvia leads to a low degree of progressivity, with inexcusably low pensions to low-earners and excessively generous pensions to high-earners. Participation in funded pillar II schemes has not brought any significant gains to pension plan sharers. Notional capital valorisation rules adopted in different countries that use the NDC-system significantly influence pension amount.
\end{abstract}

Keywords - Baltic States, NDC, pensions, public pensions.

\section{INTRODUCTION}

Ever since G. Esping-Andersen has published his famous "The Three Worlds of Welfare Capitalism" (1990), pension systems are considered a clear indicator of the welfare state characteristics and a powerful tool for the comparative analysis of social policies in different countries. Fairness, or equity, is one of the major objectives of any modern pension system. This principle has the highest priority both in the policy documents of the EU (European Commission, 2010) and OECD (2009), and in the conceptual framework for pension system analysis elaborated by the WB experts (Holzmann et al., 2008). The latter distinguish equity as a separate criterion and one of the major goals of any successful pension system. They offer the following definition: "an equitable system is one that provides the income redistribution from the lifetime rich to the lifetime poor consistent with the societal preferences in a way that does not tax the rest of society external to the system; and one that provides the same benefit for the same contribution".

The "degrees of justice" (fairness, equity) and even the understanding of the meaning of these terms vary across countries, as well. As noted by Ebbinghaus and Neugschwender (2011), systematic cross-national analyses of pension income inequality often face the problem of long time-lag between accumulating pension rights over an entire working life and withdrawing pensions after retirement. Today's income of current pensioners reflects the combined effects of past and current regulation, while reforms enacted today may only gradually affect current retirees. There are two possible strategies to cope with this timelag between policy changes and their likely effect. The first is a prospective simulation - by applying a detailed model of today's rules to possible life-course trajectories in estimating future in- comes, the result depends on multiple assumptions about future employment careers, demographic changes, future returns on capital, and stability of pension rules. The second way is to link outcomes at a point in time with a retrospective analysis of the preceding development, which is the common method adopted in most national and comparative studies.

The retrospective analysis of average pension levels, replacement rates and distributions of pension benefits by size (see, for example, Rajevska 2013a, 2013b, 2014) performed with the assistance of the historic data shares the already noted limitations of empirical method. Statistical data include pension benefits of those who retired at different stages of the pension reform, or even before the pension reform.

A reliable set of prerequisite prognostic data necessary for prospective simulation is lacking. Pension legislation in all three Baltic countries is a subject to frequent amendments; therefore, the use of prospective simulation would be precarious.

The author, therefore, chose to apply a combination of both methods and to run a retrospective simulation: to calculate theoretical benefits for a number of model cases for a certain point in the past. The aim was to compare pensions a "typical" person retiring in December 2014 in Estonia, Latvia and Lithuania could have been granted.

\section{Methodology of Research}

A generic case for simulation is a person

- with 40 uninterrupted years of service (the strict condition of unbroken service record in post-reform years, i.e. after 1995 in Lithuania, 1996 in Latvia and 1999 in Estonia);

- retiring at the end of 2014 at an official pensionable age (i.e. 63 years for men and 62.5 years for women in Estonia; 62 years and 3 months for both sexes in Latvia; 63 years for men and 61 year for women in Lithuania);

- having no dependents during the last year of employment;

- not eligible for any extras for children or other bonuses and supplements;

- not participating in pillar II;

- throughout whole career had average nationwide insured wage - baseline case (or, alternatively, was earning 50\% / $75 \% / 125 \% / 200 \% / 250 \%$ of average insured wage).

Computation steps included the following:

1. Calculation of gross pension benefit in accordance with the rules as were in force in December 2014 - based on the normative pension legislation and, where necessary, statistical data provided by national social insurance agencies. 
2. Calculation of net pension benefit in accordance with the rules as were in force in December 2014 - in accordance with the applicable taxation rules (Skačkauskienė \& Tuncikiene, 2014).

3 . For more correct comparison amounts in euro were translated into purchasing power standards obtained at Eurostat online database.

4. Computation of the net replacement rate (net pension in relation to net last salary, in \%).

6. For Latvia only: computation of theoretical pension benefit in accordance with the notional pension capital valorisation rules as per newly amended law or as per Swedish / Polish / Italian NDC rules (Axelsson et al., 2013, OECD, 2013).

\section{Calculus of Theoretical Pension Benefits and RePlacement Rates}

This section provides a brief description of old-age pension formulae used in the Estonian, Latvian and Lithuanian pension systems and describes step-by-step calculation for model cases.

\section{A. Estonia}

The first-pillar benefit in Estonia comprises of two main components: a non-contributory basic pension and an insurance component, based on which it is called a point-system. A person is annually awarded with a number of points that are equal to the ratio between his/her salary and nationwide average insured wage in the respective year (average insured wage differs from average wage, since the first takes into account those unemployed, on sick-leave, on maternity or child-care leave, etc.). Thus, if one's salary is equal to the average insured wage $-\mathrm{s} /$ he gets one point, if it is twice higher than average - two points, if twice lower 0.5 points, and so on. The points earned throughout the working career are then summarised, and the sum multiplied by the monetary value of one year. There is also the third component for the pre-reform service period: all pre-reform years of service (i.e. those before 1 January 1999) have a value of one point, irrespectively of actual earnings.

TABLE I

Theoretical Pensions and Replacement Rates in Estonia

\begin{tabular}{|l|c|c|c|c|c|c|}
\hline & 0.5 A & 0.75 A & 1 A & 1.25 A & 2 A & 2.5 A \\
\hline Basic pension & \multicolumn{7}{|c|}{126.82} \\
\hline $\begin{array}{l}\text { Pre-reform } \\
\text { component }\end{array}$ & \multicolumn{7}{|c|}{113.23} \\
\hline $\begin{array}{l}\text { Insurance } \\
\text { component }\end{array}$ & 34.74 & 56.62 & 75.59 & 94.36 & 150.98 & 188.72 \\
\hline Gross pension & 277.79 & 296.67 & 315.54 & 334.41 & 391.03 & 428.77 \\
\hline Net pension & 277.79 & 296.67 & 315.54 & 334.41 & 383.62 & 413.82 \\
\hline Net pension, PPS & 399.64 & 426.78 & 453.93 & 481.08 & 551.88 & 592.73 \\
\hline Gross wage & 396.38 & 594.56 & 792.75 & 990.94 & 1585.50 & 1981.88 \\
\hline Net wage & 345.90 & 504.45 & 663.00 & 821.55 & 1297.20 & 1614.30 \\
\hline Replacement rate & $80.3 \%$ & $58.8 \%$ & $47.6 \%$ & $40.7 \%$ & $29.6 \%$ & $25.6 \%$ \\
\hline
\end{tabular}

Both the basic component and the monetary value of one point are annually indexed. In December 2014, the basic pension was equal to 126.8183 EUR and one point - to 4.718 EUR. Pension formula allows for easy calculation of respective benefits to our model cases: a person retiring at the end of 2014 with a 40-year record would have 16 years in post-reform and 24 years in pre-reform periods, respectively. Income tax rate in December 2014 $20 \%$, tax exempt on pensions was set at 354 EUR, on wages - at 144 EUR. Average insured wage (A) in 2014 was 792.75 EUR, purchasing power parity ratio -0.695120 . This information is sufficient for completing Table I with the results of calculations.

\section{B. Lithuania}

Calculus for Lithuania is more complicated. Pension formula is similar to the Estonian one, and also consists of two main components: non-contributory basic pension and insurance component based on pension points, but has some important distinctions. Firstly, basic pension is not flat, but depends on the length of service - the longer record the higher pension (however, if a person's earnings in a certain calendar year were below the official minimum wage, this year is not counted in full, the record for it shall be proportionally shorter). Secondly, not the nationwide insured wage value is used as denominator for pension point count, but the latter is discretionary set by the government (called "insured income"), and revised on an irregular basis. One point value is equal to $0.5 \%$ of the said insured income. Thirdly, for each year of pre-reform employment (i.e. before 1994) an individual gets as many pension points as is his/her average annual point number in the post-reform period.

Thus, the first stage of calculus is to calculate the basic pension, equal for all persons having the same length of record. It, in its turn, consists of two parts: "main part" (in December 2014 114.79 EUR) and "bonus" for long service (in December 2014 3.13 EUR for each year in excess of 30-year record), which in total gives $146.09 \mathrm{EUR}^{1}$.

The second stage of calculus is to compare historical statistical data on average insured wages with official minimum wages and with "insured income" values - see Table II - in order to obtain the number of points earned by a baseline theoretical pensioner.

TABLE II

Average Pension Points in Lithuania in 1995-2014

\begin{tabular}{|l|c|c|c|c|c|c|c|}
\hline Year & $\begin{array}{c}\text { Average } \\
\text { wage * }\end{array}$ & $\begin{array}{c}\text { Insured } \\
\text { income }\end{array}$ & Points & Year & $\begin{array}{c}\text { Average } \\
\text { wage }\end{array}$ & $\begin{array}{c}\text { Insured } \\
\text { income }\end{array}$ & Points \\
\hline 1995 & 425.30 & 427.00 & 0.996 & 2005 & 336.90 & 300.58 & 1.120 \\
\hline 1996 & 556.20 & 538.00 & 1.034 & 2006 & 396.30 & 332.75 & 1.191 \\
\hline 1997 & 702.60 & 694.00 & 1.012 & 2007 & 474.50 & 389.57 & 1.218 \\
\hline 1998 & 827.00 & 845.00 & 0.979 & 2007 & 559.10 & 418.84 & 1.335 \\
\hline 1999 & 851.00 & 886.00 & 0.960 & 2009 & 516.40 & 431.30 & 1.197 \\
\hline 2000 & 867.00 & 886.00 & 0.979 & 2010 & 496.00 & 431.30 & 1.150 \\
\hline 2001 & 893.00 & 886.00 & 1.001 & 2011 & 507.30 & 431.30 & 1.176 \\
\hline 2002 & 918.10 & 886.00 & 1.036 & 2012 & 518.20 & 431.30 & 1.201 \\
\hline 2003 & 280.10 & 259.13 & 1.081 & 2013 & 550.40 & 431.30 & 1.276 \\
\hline 2004 & 303.80 & 269.86 & 1.126 & 2014 & 574.60 & 431.30 & 1.332 \\
\hline \multicolumn{6}{|c|}{ Total sum of points } & $\mathbf{2 2 . 4 0 9}$ & \multicolumn{7}{c|}{ Average points per year } & $\mathbf{1 . 1 2 0}$ \\
\hline
\end{tabular}

* - figures for 1995-2002 are in Litas, later - in euro

\footnotetext{
One exception would be made for a person with $50 \%$ AW: the bonus would be slightly lower, because there were 5 years $(1997,1998,1999,2013$ and 2014) when $50 \%$ of average insured wage fell short of the official minimum wage, so bonus part for those years is proportionately discounted.
} 
Pensions are not taxed, while gross salaries are taxed both with income tax of $15 \%$ (tax exempt in December 2014 was 165.22 EUR) and social insurance contributions of $9 \%$.

Purchasing power parity ratio for Lithuania in 2014 was 0.554340 . Now there are enough raw data for the final stage of calculations shown in Table III.

TABLE III

Theoretical Pensions and Replacement Rates in Lithuania

\begin{tabular}{|l|c|c|c|c|c|c|}
\hline & $\mathbf{0 . 5} \mathbf{A}$ & $\mathbf{0 . 7 5} \mathbf{A}$ & $\mathbf{1 A}$ & $\mathbf{1 . 2 5} \mathbf{A}$ & $\mathbf{2} \mathbf{A}$ & $\mathbf{2 . 5} \mathbf{A}$ \\
\hline Basic pension & 142.96 & \multicolumn{5}{|c|}{146.09} \\
\hline $\begin{array}{l}\text { Insurance } \\
\text { component }\end{array}$ & 48.29 & 72.44 & 96.58 & 120.73 & 193.16 & 241.46 \\
\hline Net pension & 191.25 & 218.52 & 242.67 & 266.82 & 339.25 & 387.53 \\
\hline Net pension, PPS & 345.00 & 393.99 & 437.55 & 481.11 & 611.78 & 698.90 \\
\hline Gross wage & 287.30 & 430.95 & 574.60 & 718.25 & 1149.2 & 1436.5 \\
\hline Net wage & 247.01 & 337.20 & 467.30 & 580.35 & 913.69 & 1135.92 \\
\hline Replacement rate & $77.4 \%$ & $61.0 \%$ & $51.8 \%$ & $46.0 \%$ & $37.1 \%$ & $34.1 \%$ \\
\hline
\end{tabular}

With the only exception for half-average wage earners, replacement rates are higher than Estonian ones.

\section{Latvia}

Latvian first-pillar benefits do not include any basic non-contributory component. The benefit is earned by all insured individuals by "directing" part of their social insurance contributions to the personalised notional pension capital account. No actual money transfer takes place, this capital exists only as a record at the State Social Insurance Agency database, and the whole scheme is known as NDC: notional (or, in another abbreviation expansion, also "non-financial") defined-contribution. The pension value is the sum of notional capital at retirement divided by the projected life expectancy at the retirement age. The notional capital for the pre-reform period (years of service prior to 1996) is called "initial capital" and calculated based on average actual personal earnings in 1996-1999.

The accrued notional capital is annually valorised (up-rated) in line with increase in the covered wage bill. These annual indices imitate the role of interest rates in funded schemes. When the total amount of wages on a nationwide scale drops below the last year figure - the interest rate is negative.

Thus, the first stage of Latvian pension formula is to calculate the accrued (Table IV) and the initial (Table V) notional capital for the baseline case: a person with average insured wage.

Likewise, for calculating the initial pension capital for pre-reform years of service it is necessary to multiply the wages in 1996-1999 by cumulative valorisation indices and obtain the average. Further, this "average" is multiplied by the length of pre-reform record (with a 40 -year record a theoretical person would have 19 post-reform and 21 pre-reform years of service), and "taxed" at $20 \%$.

Total accrued pension capital, therefore, is 63,558.59 EUR for a person with average insured wage or, respectively, $50 \%$ of this amount for a person with $50 \%$ of average wage, $75 \%$ of this amount for a person with $75 \%$ of average wage, etc. Other pension formula variables include: G-coefficient (life expectancy at retirement), which was equal to 18.50 for persons aged 62 full years in 2014 (Dārziņa, 2014), income tax rate of 24\% (tax exempt 235 euro for pensioners and 75 euro for salaried persons), social insurance contribution rate on gross wages $-10.5 \%$, purchasing power parity -0.630549 . This allows for further calculations, whose results are presented in Table VI.

TABLE IV

Notional Pension Capital Accumulated in 1996-2014

\begin{tabular}{|c|c|c|c|c|c|}
\hline Year & $\begin{array}{c}\text { Average } \\
\text { wage }\end{array}$ & $\begin{array}{c}\text { Contributions } \\
\text { paid }\end{array}$ & $\begin{array}{c}\text { Annual } \\
\text { index }\end{array}$ & $\begin{array}{c}\text { Cumulative } \\
\text { index }\end{array}$ & $\begin{array}{c}\text { Notional } \\
\text { capital }\end{array}$ \\
\hline 1996 & 131.41 & 315.38 & 1.0000 & 4.7919 & 1511.26 \\
\hline 1997 & 158.17 & 379.61 & 1.0300 & 4.6523 & 1766.05 \\
\hline 1998 & 174.40 & 418.56 & 1.1200 & 4.1538 & 1738.63 \\
\hline 1999 & 182.13 & 437.11 & 1.1170 & 3.7187 & 1625.51 \\
\hline 2000 & 194.39 & 466.54 & 1.0690 & 3.4787 & 1622.95 \\
\hline 2001 & 206.83 & 496.39 & 1.0835 & 3.2106 & 1593.73 \\
\hline 2002 & 219.93 & 527.83 & 1.0453 & 3.0715 & 1621.23 \\
\hline 2003 & 245.19 & 588.46 & 1.1645 & 2.6376 & 1552.11 \\
\hline 2004 & 272.96 & 655.10 & 1.1754 & 2.2440 & 1470.06 \\
\hline 2005 & 312.92 & 751.01 & 1.1712 & 1.9160 & 1438.92 \\
\hline 2006 & 389.77 & 935.45 & 1.2333 & 1.5535 & 1453.26 \\
\hline 2007 & 518.71 & 1244.90 & 1.3593 & 1.1429 & 1422.80 \\
\hline 2008 & 625.65 & 1501.56 & 1.3106 & 0.8720 & 1309.43 \\
\hline 2009 & 560.31 & 1344.74 & 0.9622 & 0.9063 & 1218.74 \\
\hline 2010 & 537.52 & 1290.05 & 0.7978 & 1.1360 & 1465.50 \\
\hline 2011 & 547.68 & 1314.43 & 0.9945 & 1.1423 & 1501.46 \\
\hline 2012 & 565.28 & 1356.67 & 1.0618 & 1.0758 & 1459.51 \\
\hline 2013 & 594.06 & 1425.74 & 1.0758 & 1.000 & 1425.74 \\
\hline 2014 & 622.50 & 1494.00 & 1.0766 & 1.000 & 1494.00 \\
\hline & & & Total accumulated notional capital: & $\mathbf{2 8 , 6 9 0 . 8 8}$ \\
\hline
\end{tabular}

TABLE V

Initial Pension Capital

\begin{tabular}{|c|c|c|c|}
\hline & Average wage & Cumulative index & Valorised wage \\
\hline 1996 & 131.41 & 4.7919 & 629.70 \\
\hline 1997 & 158.17 & 4.6523 & 735.85 \\
\hline 1998 & 174.40 & 4.1534 & 724.43 \\
\hline 1999 & 182.13 & 3.7187 & 677.30 \\
\hline \multicolumn{3}{|c|}{ Average wage $1996-1999\left(\mathrm{~W}_{\mathrm{ave}}\right)$} & $\mathbf{6 9 1 . 8 2}$ \\
\hline Initial capital $=\mathrm{W}_{\text {ave }} \times 12 \times 21$ pre-reform years $\times 20 \%$ & $\mathbf{3 4 , 8 6 7 . 7 1}$ \\
\hline
\end{tabular}

TABLE VI

Theoretical Pensions and Replacement Rates in Latvia

\begin{tabular}{|l|c|c|c|c|c|c|}
\hline & $\mathbf{0 . 5} \mathbf{A}$ & $\mathbf{0 . 7 5} \mathbf{A}$ & $\mathbf{1 A}$ & $\mathbf{1 . 2 5} \mathbf{A}$ & $\mathbf{2} \mathbf{A}$ & $\mathbf{2 . 5} \mathbf{A}$ \\
\hline Gross pension & 143.15 & 214.72 & 286.30 & 357.87 & 572.60 & 715.75 \\
\hline Net pension & 143.15 & 214.72 & 273.99 & 328.38 & 491.58 & 600.37 \\
\hline Net pension, PPS & 227.02 & 340.54 & 434.52 & 520.79 & 779.60 & 952.14 \\
\hline Gross wage & 311.25 & 466.88 & 622.50 & 778.13 & 1245.00 & 1556.25 \\
\hline Net wage & 229.71 & 335.57 & 441.42 & 547.28 & 864.85 & 1076.56 \\
\hline Replacement rate & $62.3 \%$ & $64.0 \%$ & $62.1 \%$ & $60.2 \%$ & $56.8 \%$ & $55.8 \%$ \\
\hline
\end{tabular}


As far as Latvia is concerned, the model above allows testing one more hypothesis: whether those persons who voluntarily joined pillar II benefited from that decision or not.

Let us consider the same average wage earner, who made a decision to participate in pillar II starting from 01/01/2004 and compare $\mathrm{him} /$ her to the baseline model case, a non-participant in the funded scheme.

Pillar II commenced at the end of 2001 in Latvia; however, private pension funds were admitted to this market from 2003. Private funds started massive advertising and attracted a lot of voluntary participants in the second half of 2003 and at the beginning of 2004. Let us assume that the test object was one of them.

Such person's contributions to pillar I would be lower, since part of them (one tenth in 2004-2006 and 2009-2012, one fifth in 2007 and in 2013-2014, and two fifths in 2008) were directed to pillar II. By applying the same algorithm as in Table IV above, the accrued notional capital in that case would become equal to 27,693.78 EUR, which was 997.10 EUR lower than that in the baseline case. The initial capital is not affected by person's participation in pillar II.

After deduction of the State Social Insurance Agency administrative fees, pillar II contributions were directed to one of private pension funds. A person could choose a pension plan with an active, balanced or conservative investment strategy.

For ease of calculations, let us suppose that annual average yields (as presented in FCMC reports) can be extended to the whole corresponding year. The results of calculations are presented in Table VII (the author omits a detailed description of intermediate cumbersome computation of compound interests).

TABLE VII

Theoretical Pension of Pillar II Participant in Latvia

\begin{tabular}{|l|c|c|c|c|}
\hline & $\begin{array}{c}\text { Active } \\
\text { strategy }\end{array}$ & $\begin{array}{c}\text { Balanced } \\
\text { strategy }\end{array}$ & $\begin{array}{c}\text { Conserva- } \\
\text { tive strategy }\end{array}$ & $\begin{array}{c}\text { "Average" } \\
\text { strategy }\end{array}$ \\
\hline $\begin{array}{l}\text { Accumulated capital, } \\
\text { EUR }\end{array}$ & 1098.98 & 1121.71 & 1116.16 & 1101.88 \\
\hline Net pension, EUR & 274.34 & 274.41 & 274.40 & 274.35 \\
\hline $\begin{array}{l}\text { Gain compared } \\
\text { to non-participant }\end{array}$ & $0.35 \mathrm{EUR}$ & $0.42 \mathrm{EUR}$ & $0.41 \mathrm{EUR}$ & $0.36 \mathrm{EUR}$ \\
\hline
\end{tabular}

Pillar II legislation in Estonia and Lithuania requires not only directing part of existing social tax to private pension funds, but also making additional contributions (thus, changing the net wage compared to the baseline scenario). It also offered more choices to participants regarding split of contributions between pillar I and pillar II in some years, as well as a possibility to freeze the payments or even to leave the funded scheme. Therefore, it is more difficult to define a "typical" or "average" case for modelling there (at least, based on the information available in open access sources). The capital accumulated in pillar II is only a hundred euros higher than the capital "lost" in pillar I. Thus, in contrast to the author's initial expectations, there practically is no difference either a person participated in pillar II or not, as well as either the chosen pension plan was active, balanced or conservative.
Since the resulting figures are averaged and close to zero, in practice this means that some of voluntary pillar II participants could face though small but loss.

\section{FINDINGS}

The obtained figures (Fig. 1) clearly demonstrate very different patterns of pension sizes depending on person's wage during working life. Small coloured rhombi mark the levels of net average salaries in 2014 expressed in PPS. Despite significantly lower salaries in Latvia, an average wage earner would get practically the same pension in Latvia and Lithuania.

The Latvian case is an example of almost linear proportionality: twofold earnings would bring twofold pension, the only shadow of progressivity is obtained through tax exempt.

The difference in replacement rate for low- and high-earner in Latvia is less than 10 percentage points. With the lowest average wages, Latvia has the highest replacement rates.

On the opposite side, there is Estonia with a strongly pronounced redistribution from rich to poor: among all three countries its pension system provides the highest replacement rate for low-earners $-80.3 \%$ and the lowest replacement rates for high-earners $-25.6 \%$, the amplitude reaching almost 55 percentage points. To a great degree, this progressivity is achieved through an egalitarian approach to pre-reform service record, where everyone gets exactly one pension point for one year.

Lithuania demonstrates an intermediate example of distribution being, however, much closer to the Estonian pattern than to the Latvian one. The difference in replacement rates for low- and high-earners reaches 43 percentage points.

Thus, in Latvia the poor are poorer, and the rich are richer. Pensions of low-earners (50\% and $75 \%$ of average wage) are the lowest in the Baltics, while those of high-earners (125\%, 200\% and $250 \%$ of the average) are the highest in the region. Pensioners, who had average wage during their working careers, can afford a very similar living standard: the purchasing power of their pension is almost the same - 454 PPS in Estonia, 438 PPS in Lithuania and 435 PPS in Latvia. One PPS is close to a purchasing power of one euro in Germany and the Netherlands, so, actually, 40 years of uninterrupted service record in any of the Baltic States entails a very modest living standard compared to other EU member states.

It is interesting to note that the case of three Baltic States is in contrast with the findings of Raj Aggarwal and John Goodell (Aggarwal \& Goodell, 2013) for the OECD countries. Those scholars have demonstrated that average relative pension levels are negatively related to pension progressivity, i.e. the lower average pensions are found in the countries with a high degree of progressivity. This is not the case for Estonia, Latvia and Lithuania, where the situation is the opposite: the country with the highest average pensions (Estonia) has the most progressive distribution.

Another regularity evidenced in the OECD does not work in the Baltics, either: Aggarwal and Goodell contend that lower mutual social trust encourages pension progressivity. For measuring social trust they use a variable taken from the World Values Survey - namely, the percentage responding affirmatively to the question that most people can be trusted. 


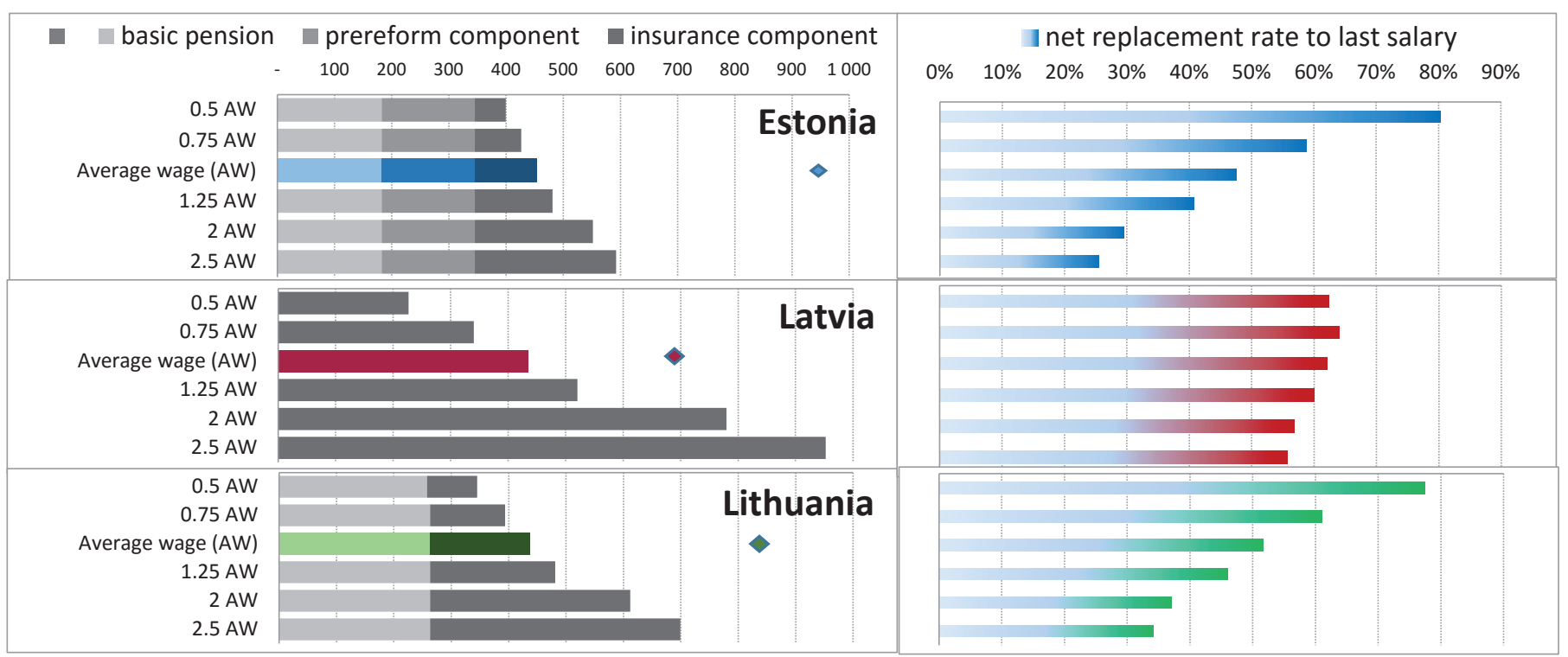

Fig. 1. Theoretical pensions and replacement rates.

Respondents of Estonia, Latvia and Lithuania were also asked the same question at the $4^{\text {th }}$ wave of the European Values Study in 2008 (EVS 2011) and the least social trust was observed in Latvia ( $25.5 \%$ of respondents), where pension system was the least progressive, Estonians having the most progressive pension system returned the rate of $32.6 \%$ (which was higher than EU-27 average of $32.4 \%$ ), Lithuanians were somehow more suspicious: $29.9 \%$ of them trusted in people.

Aggarwal and Goodell proceed from the premise that national pension plans in democratic states reflect the expectations of their citizens. It works for the OECD countries, but does not work for Latvian case, where the pension reform was to a great extent choreographed by foreign experts and bank lobbyists.

\section{EfFects of Changes in Notional Capital Valorisation Rules}

Another set of simulations was run in relation to potential modifications in computing valorisation indices. As mentioned above, the Latvian formula uses annual increase in the covered wage bill in this role. And, until 2015, in the years with the wagebill decrease instead of its increase, the indices fell below one (see Table IV above) causing melting of already accrued notional capital. On 27/06/2015 the Latvian Parliament adopted amendments to the Law on State Pensions introducing additional rules for calculation of annual indices - the index will not be allowed to fall below one (but, on the other hand, will not be allowed to rise above 1.15). Should the result of calculation for a certain year $t$ be below one, exactly one would be used for pension capital indexation. Balancing would be achieved in the years following year $t$ : should the result of calculation for year $t+1$ be above one, for pension capital indexation would be used not this figure, but the product of calculated indices for both years. If the product is still below one - the capital in year $t+1$ is again indexed with 1.00 and the next year $t+2$ shall also be included into balancing, and so on, until all negative indices are compensated by positive indices. This rule has a retroactive effect, and shall be applied to valorisation indices from 2009 and further, and all pensions granted in 2010-2015 shall be recalculated (the terms have not been defined yet and shall depend on state fiscal situation). The author calculated what would be the pensions, should these rules be in force in 2014 (interim steps of calculation omitted in Table VIII):

TABLE VIII

Theoretical Pensions and Replacement Rules in Accordance With Revised Valorisation Rules

\begin{tabular}{|l|c|c|c|c|c|c|}
\hline & $\mathbf{0 . 5} \mathbf{A}$ & $\mathbf{0 . 7 5} \mathbf{A}$ & $\mathbf{1} \mathbf{A}$ & $\mathbf{1 . 2 5} \mathbf{A}$ & $\mathbf{2 ~ A}$ & $\mathbf{2 . 5} \mathbf{A}$ \\
\hline $\begin{array}{l}\text { Net pension, old rules } \\
\text { (EUR) }\end{array}$ & 143.15 & 214.72 & 273.99 & 328.38 & 491.58 & 600.37 \\
\hline $\begin{array}{l}\text { Net pension, new rules } \\
\text { (EUR) }\end{array}$ & 160.56 & 239.44 & 300.45 & 361.46 & 544.50 & 666.53 \\
\hline Gain, EUR & 17.41 & 24.72 & 26.46 & 33.08 & 52.92 & 66.16 \\
\hline Gain, \% & $12.2 \%$ & $11.5 \%$ & $9.7 \%$ & $10.1 \%$ & $10.8 \%$ & $11.0 \%$ \\
\hline $\begin{array}{l}\text { Replacement rate, } \\
\text { new rules }\end{array}$ & $69.9 \%$ & $71.4 \%$ & $68.1 \%$ & $66.0 \%$ & $63.0 \%$ & $61.9 \%$ \\
\hline $\begin{array}{l}\text { Gain in replacement } \\
\text { rate, percentage points }\end{array}$ & +7.6 & +7.4 & +6.0 & +5.8 & +6.2 & +6.1 \\
\hline
\end{tabular}

Although the procedure for uprating the pensions granted in 2010-2015 in accordance with the amended law has not been developed yet, the author's calculations show that those who retired at the end of 2014 may expect increase in their net pensions by approximately $10 \%$. In general, the relative increase will be the highest for those retired at the beginning of 2013, who suffered most from negative indices, and the lowest for those who retired in the 2nd half of 2015, who suffered least.

But what would happen to theoretical pensions in 2014, if the newly adopted valorisation formula were in force from the very commencement of NDC in Latvia in 1996? Or how Latvian pensions would look like, should Latvia have chosen the same method as other NDC-countries: Poland, Sweden or Italy? The results for the theoretical baseline average wage earner would be significantly discrepant - see Fig. 2 (interim stages of calculations are not shown). 


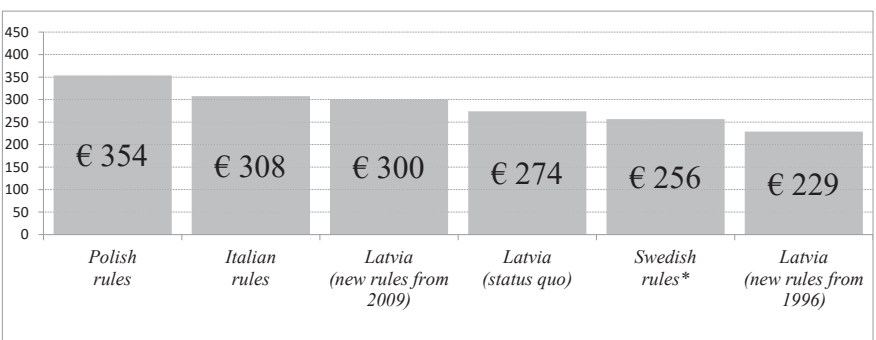

* - without regard to inheritance gains

Fig. 2. Theoretical net pension benefit for an average wage earner with a 40 -year record depending on methodology of notional capital valorisation.

As can be seen, Polish rules (increase in countrywide wagebill, but not lower than inflation rate and no diminution) would produce by now the most generous pension to a Latvian average wage earner. The second place is held by the Italian method (moving 5-year average of annual increase in nominal GDP). Then the Latvian new formula follows prescribing retroactive recalculation of capital indices starting from 2009. Should, however, these new rules be applied to earlier "fat" years, not allowing indices be above 1.15 , the result would be much worse. The Swedish formula (moving 3-year inflation-adjusted average of annual increase in an average wage) returns quite low pension, either. It should be noted, however, that such rating is not valid for all years.

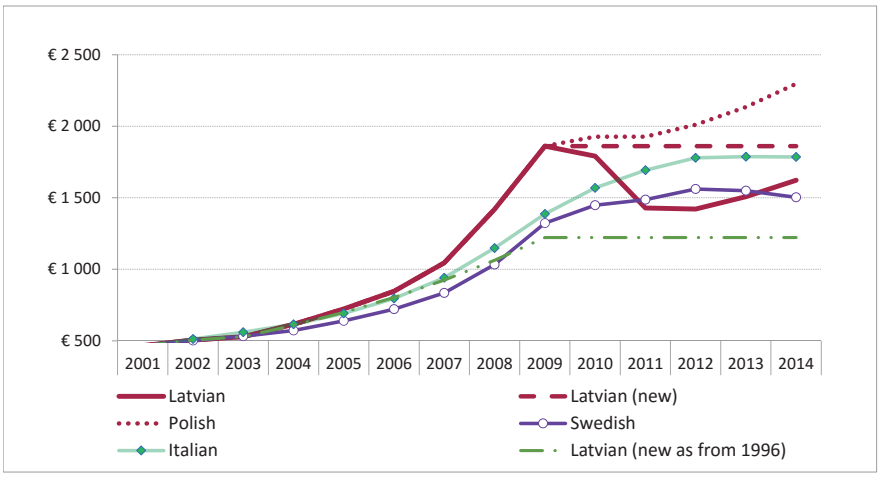

Fig. 3. Theoretical trajectories of notional capital valorisation depending on methodology of calculation.

Figure 3 shows, as an example, the value of contributions made in 2000 from an average insured wage (i.e. 466.54 EUR) valorised according to different methods over a period from 2006 till 2014 (in the first five years before 2006 the lines go very close to each other, since a sufficient time period is needed to make the effect visible. The relative positions of trajectories vary: until 2009 "Polish" and "Latvian" lines coincide, but afterwards the former goes up, while the latter falls down; in 2011-2013 "Swedish" method guaranteed higher pensions than "Latvian", but in other years - vice versa. "Italian" method gave lower results than "Latvian" before 2010, but then the roles reversed.)

It should be noted that there is no "first-best" methodology: each of them has its advantages and disadvantages: the method used in Latvia at present and its new amended version guarantee the fastest matching PAYG assets with its liabilities, but does not take into consideration inequitable inter-cohort relations; the Polish rules prevent individual notional account accumulations from diminution, but can generate excessively high liabilities to social insurance budget. The Italian formula links notional capital growth to overall economic capacity of the state, 5-year moving average helps avoid sharp variations but does not guarantee notional capital from melting in the long run. Swedish valorisation formula does not react to a decrease in the number of working population - instead, the system uses additional balancing mechanism of matching assets with liabilities making the total computation extremely complicated.

\section{CONCLUSiON}

The variations between the Baltic States can be substantially explained by differences in pension system design elements. Firstly, a lack of any non-contributory element (like basic pension) in Latvia leads to a low degree of pension progressivity, with inexcusably low pensions to low-earners and excessively generous pensions to high-earners. Secondly, a very different approach was chosen for conversion of pre-reform record into a new pension scheme. The most equitable method of translating the pre-reform service record into new systems was chosen by Lithuania, the Estonian approach is too egalitarian, while the Latvian formula looks more like an extemporary measure. Thirdly, Lithuania, contrary to the other two countries, has a unique mechanism, rewarding not only for financial contributions but also for the time in service.

The capital accumulated in pillar II has not practically produced any gain to voluntary participants of the funded schemes. Some of them could even face though small but loss.

Notional capital valorisation rules adopted in different countries using NDC-schemes in their pension systems significantly influence the pension amount.

\section{ACKNOWLEDGMENT}

The paper has been supported by the National Research Program 5.2.6 EKOSOC-LV.

\section{REFERENCES}

Aggarwal, R., \& Goodell, J. W. (2013). Political-economy of pension plans: Impact of institutions, gender, and culture. Journal of Banking \& Finance, 37 (6), 1860-1879. http://dx.doi.org/10.1016/j.jbankfin.2012.05.008

Axelsson, R., Wadensjo, E. \& Baroni, E. (2010). ASISP Annual National Report 2010. Pensions, Health and Long-term Care. Sweden. Retrieved August 20, 2015, from http://socialprotection.eu/files_db/1145/asisp_ANR10_Sweden. pdf

Dārzina, L. (2014). Mainīta pensijas aprēkina koeficienta G noteikšanas kārtība „Latvijas Vēstneša” portāls „Par likumu un valsti”, 14/01/2014. Retrieved August 20, 2015, from http://www.lvportals.lv/visi/skaidrojumi/260283

Ebbinghaus, B., \& Neugschwender, J. (2011). The Public-Private Pension Mix and Old Age Income Inequality in Europe. In B. Ebbinghaus (Ed.), The Varieties of Pension Governance: Pension Privatization in Europe (pp. 384423). Oxford, England: Oxford University Press. http://dx.doi.org/10.1093/ acprof:oso/9780199586028.003.0014

European Commission. (2010). Progress and key challenges in the delivery of adequate and sustainable pensions in Europe. European Economy, No. 71. Brussels: DG Economic and Financial Affairs.

Esping-Andersen, G. (1990). The Three Worlds of Welfare Capitalism, New York: Princeton University Press.

Eurostat (2015). Purchasing power parities (EU15=1), actual individual consumption in 2014. Retrieved from Eurostat online database.

EVS (2011): European Values Study 2008: Integrated Dataset (EVS 2008). GESIS Data Archive, Cologne. ZA4800 Data file version 3.0.0, doi: $10.4232 / 1.11004$ 
FKTK (2015). Valsts fondēto pensiju shēmas līdzekḷu pārvaldīšana - ceturkšṇa pārskati par 2005-2015. Retrieved August 20, 2015, from http://www.fktk lv/lv/statistika/pensiju-fondi/ceturksna-parskati.html

Holzmann, R.,Hinz, R. P. \& Dorfman, M. (2008). Pension Systems and Reform Conceptual Framework. Social Protection Discussion Paper 0824.

Medaiskis, T. \& Jaunkauskiene, D. (2013). ASISP country document 2013. Pensions, health and long-term care. Lithuania. Retrieved August 20, 2015, from http://socialprotection.eu/files db/1334/LT asisp CD13.pdf

OECD (2009). Policy Brief: The Benefits of Long-term Fiscal Projections. Retrieved November 1, 2015, from http://www.oecd.org/ governance/budgetingandpublicexpenditures/43836144.pdf

OECD (2013). Pensions at a Glance 2013: OECD and G20 Indicators, OECD Publishing, Paris. Retrieved August 20, 2015, from http://dx.doi.org/10.1787/ pension glance-2013-65-en

Skačkauskienè, I.\& Tuncikiene, Z. (2014). Comparative evaluation of the labour income taxation in the Baltic States, Procedia - Social and Behavioral Sciences, 110, 439-449. http://dx.doi.org/10.1016/j.sbspro.2013.12.888

Rajevska, O. (2013a). Equity criterion in pension systems assessment and its manifestation in Estonian and Latvian pension schemes. Journal of Economics and Management Research, 2, 118-130.

Rajevska, O. (2013b). Funded pillars in the pension systems of Estonia, Latvia and Lithuania. Economics and Business, 23, 83-89.

Rajevska, O. (2014). Adequacy of pensions in the Baltic region. Regional Review, 10, 41-51.

State Social Insurance Board of Lithuania (2015). Average insured earnings. Retrieved from Sodra's statistical data web-site http://atvira.sodra.lt/eneur/index.html

Vork, A. \& Paat-Ahi, G. (2013). ASISP Country document 2013: pensions, health and long-term care. Estonia. Retrieved August 20, 2015, from http://socialprotection.eu/files_db/1372/EE_asisp_CD13.pdf

VSAA (2015). Sociāli apdrošinātās personas un sociālās apdrošināšanas vidējā iemaksu alga 1996-2014. Retrieved August 20, 2013, from online database http://www.vsaa.gov.lv/lv/budzets-un-statistika/statistika?gid=1

Zilvere, R. (2013). ASISP Country Document 2013. Pensions, health and long term care. Latvia. Retrieved August 20, 2015, from http://socialprotection. eu/files db/1415/LV asisp_CD13.pdf

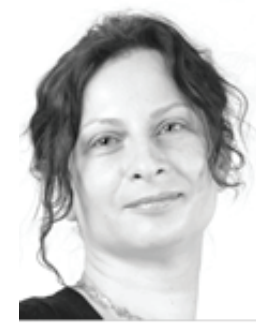

Olga Rajevska is a PhD Candidate in Public Administration, expecting to defend her Doctoral Thesis on pension adequacy and equity in the Baltic States in 2016. She holds a Master degree in Baltic Sea Region Studies (Mag. hum., 2012) and a Bachelor degree in Business Administration (1994).

She works as a Research Assistant at the Scientific Institute of Economics and Management (University of Latvia, Riga). Olga Rajevska participated in the State Research Programme "National Identity" in 2013-2014. At present, she takes part in the State

Research Programme "Ekosoc-LV". Formerly, she was engaged as an economist in private sector in the field of ship management.

The author is a member of the International Public Policy Association.

E-mail: Olga.Rajevska@lu.lv 